\title{
COMPARATIVE PERFORMANCE OF THE NATIVE PUERTO RICAN FOWL, THE WHITE LEGHORN, THE NEW HAMP- SHIRT, AND CROSSES BETWEEN THEM
}

\section{A. GonZÁlez Chapel ${ }^{1}$}

\section{INTRODUCTION}

The problem of Puerto Rico is mainly an increasing population without a corresponding increase in production. The population of the Island in 1940 was around 2,000,000 inhabitants The Island has an area of about 3,435 square miles and there were approximately 605 inhabitants per square mile of territory. During 1946 there was a rate of natural increase of 29.6 per 1,000 population, which is one of the highest birth rates of any country in the world. Thus, the population in the Island is increasing at a rate of approximately 60,000 people every year.

The people of the Island are largely dependent, directly or indirectly, upon importations from the United States for their foods from animal sources. The importations of livestock products and livestock feeds were near $\$ 50,000,000$ during the fiscal year 1947-48. The following table shows the yearly per capita supply in Puerto Rico in 1939-40 of the main foods containing animal protein as compared with an adequate diet at minimum cost as given by the Bureau of Home Economics of the United States Department of Agriculture (1933). In addition, the per cent of the supply that was imported during that year is also given.

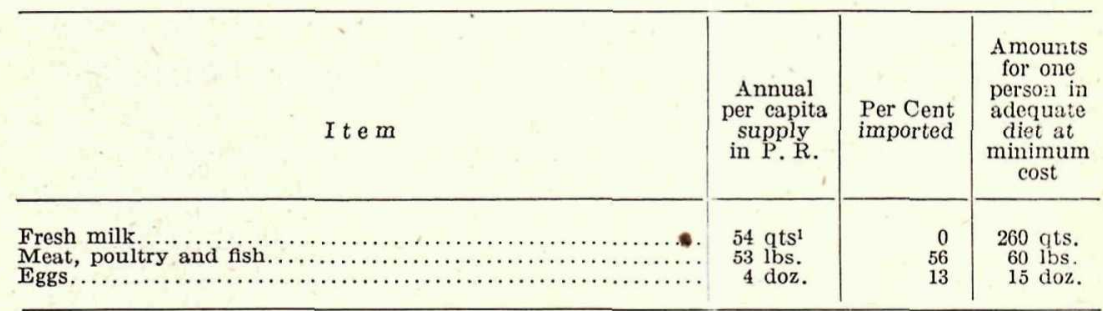

There are potentialities for considerable expansion of the livestock industry in the Island.

1 Associate Animal Husbandman. 
Poultry products are one of the chief foods in Puerto Rico. In 1935, the farm value of poultry products (meats and eggs) ranked sixth in importance among the various sources of income on farms in Puerto Rico. This value was distributed almost equally between meat and eggs. There is reason to believe that no essential change in the situation has occurred.

According to the census of 1940 , the poultry population of the Island was $1,751,292$.

During the fiscal year 1945-46, shipment of poultry and poultry products from the United States amountea to $\$ 1,362,010$. These shipments were distributed as follows:

\begin{tabular}{|c|c|c|}
\hline I $\mathrm{te} \mathrm{m}$ & Amount & Value \\
\hline \multirow[t]{2}{*}{ 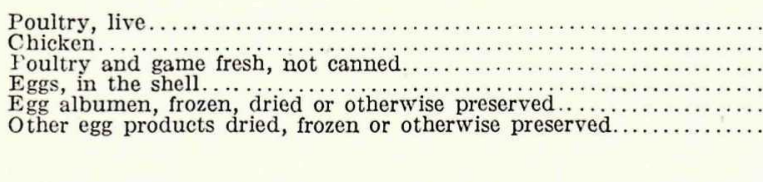 } & \multirow[t]{2}{*}{$\begin{array}{r}201 \cdot 087 \\
5,453 \mathrm{lbs} . \\
737,851 \mathrm{lbs} \\
1,589,942 \mathrm{doz} . \\
17,068 \mathrm{lbs} \\
379,583 \mathrm{lbs}\end{array}$} & $\begin{array}{r}\$ 256,632 \\
5,462 \\
291,420 \\
671,189 \\
4,973 \\
132,334\end{array}$ \\
\hline & & $\$ 1,362,010$ \\
\hline
\end{tabular}

Data on milk, not fresh, were not available.

During the fiscal year 1947-48 the value of these shipments was probably close to $\$ 3,000,000$.

If the productive capacity of the poultry were increased, Puerto Rico could not only be made more self-sufficient in regard to the present demands for poultry products, but also the nutrition of the people could be improved by increasing the consumption of the foods supplying animal proteins. The diets of Puerto Ricans are, as a rule, woefully lacking in such foods.

\section{The Problem}

The apparent obstacles to the expansion of the poultry industry in Puerto Rico are the assumed poor productivity of the native breed, the high cost of the feed, the poor management practices, and parasites and diseases.

The development of a well adapted breed with better productivity than the native would be a first step toward the development of the poultry industry and an important contribution to the Island's economy.

The native fowl is the product of interbreeding different breeds and strains, without uniformity in feather color, light in weight, and supposedly with low productive capacity and much resistance to diseases. It has also been assumed that the native 
fowl is adapted to the Island's environment and to the living conditions of the small farmers. No systematic study has been made in the past of the bird's productive capacity.

The native birds, receiving very little care and attention from the farmers, constitute an almost free source of income in the small farms of the Island. It is logical to suppose, however, that during the many generations of their existence in Puerto Rico, natural selection and some unconscious human selection could have favored development of adaptability to the general conditions in Puerto Rico.

A few flocks of imported breeds are kept by some farmers in the Island, but they are kept under conditions beyond the means of the average Puerto Rican farmer. Scant or no information about the productivity of most of these flocks is available. In the past it has been assumed that the imported breeds in Puerto Rico have laid well and developed to good size, but that they were very susceptible to disease and unadapted to the environment on farms.

Rhoad (1941, p. 512) stated,

Farm animals are kept for the most part in an environment that it is in many ways artificial, man created. Much of the success of the livestock industry depends upon our ability to furnish a favorable environment in which livestock can develop and produce to the limit of their inherent capacities. To the extent that this cannot be done economically, it is necessary to select and modify breeds to fit the natural environment, of which climate is a major part.

A study of the productive capacity of the native fowl in comparison with that of standard breeds reared under similar conditions and studies of an exploratory nature on the possibilities of crosses between the native and standard breeds seem logically the first step to follow.

Thus, the objectives of this study were to find out any practical differences between the native fowl and the standard breeds in Puerto Rico in respect to their productive capacity; if differences were apparent, to determine which breeds were the best in the different characters considered; and to determine the performance of crosses of the native with the standard breeds.

\section{REVIEW OF LITERATURE}

The average temperature in Puerto Rico is somewhat lower and more uniform than in other places in the tropics located at 
the same latitude. The mean annual temperature for the Island is around $76^{\circ}$, varying in different places according to the elevation and topography.

In the tropics, unlike in temperate climates, the average monthly temperature is subject to small variation during the year, but marked differences in temperature occur within the day period. The highest temperature occurs generally around noon and the lowest in the early morning.

The average minimum annual temperature for the Island is $66.9^{\circ}$ and the average maximum annual temperature is $86^{\circ}$. At Aibonito, where the livestock production farm of the Agricultural Experiment Station is located, the lowest temperature recorded is $40^{\circ}$ and the highest $92^{\circ}$ (Harris, 1947).

Records of rainfall in Puerto Rico (Thorp, 1941) indicate an average maximum annual precipitation of 136 inches and a minimum of 27 inches. Because of the high mean temperatures, the effectiveness of the rainfall is considerably less than it would be in cooler climates, and it is further reduced below that of many cooler regions because of the almost constant air movement.

Humidity is nearly always high. In some parts of the Island it is over 75 per cent most of the time.

The effect of climate and the external environment upon humans and animals have been studied extensively in the last few years. Lush (1945) pointed out that this interest arises mainly from tropical and subtropical regions for which none of the established breeds of animals seem well suited.

Observations made on human beings tend to indicate a lowered basal metabolism in the people of the tropics as stated by Mukherjee and Gupta (1931) and Sherman (1941). Heinbecker (1928), on the other hand, found that the basal metabolic rate of 3 Eskimos was 33 per cent greater than standards for subjects in the temperate zone. Mason (1940) found that 13 out of 21 English and American women who changed their residence from temperate to tropical climate showed a distinct fall of metabolic rate in the tropics, averaging approximately 10 per cent. In a study of basal metabolism as affected by atmospheric conditions McConnell (1925) concluded that the zone of minimum metabolic rate was between $75^{\circ}$ and $83^{\circ}$ effective temperature. Roddis and Cooper (1926) found in 173 naval officers in the tropics that blood pressure was reduced $10-15 \mathrm{~mm}$. $\mathrm{Hg}$. below textbook standards. 
On animals the literature is more extensive and shows, as in human beings, the definite effect of the external environment upon their physiological responses.

The resistance of animals to cold is much greater than that to heat, according to Brody (1940) who also concluded that the thermoneutrality zone varies with the season, and the temperature to which the animal is acclimatized, but the maximum temperature is about $85^{\circ} \mathrm{F}$.

Regan and Richardson (1938) found that increasing the room temperature caused an increase in respiration rate of dairy cattle, a decrease in pulse rate, and after $80^{\circ} \mathrm{F}$. a rise in body temperature, anorexia and a decline in milk flow. Rhoad (1942) tested more than 150 cows, heifers and steers of the Iberia Livestock Experiment Farm, in Jeanerette, Louisiana, for adaptability to tropical climatic conditions and claimed that as a result the variously bred types of cattle in the Jeanerette herds can be classified from the most adaptable to the least adaptable type. The same author (1936) suggested that the loss of energy in dairy cattle as a result of high temperature is in a large way responsible for the low production records of European dairy cattle in the tropics. Forbes et al. (1926) found that the per cent of heat emission as latent heat of water vapor increased with an increase in temperature. Manresa and Orig (1941) implied that the ability to withstand external heat without significantly raising the temperature of the body might be used as a test for adaptability of different breeds of cattle to a given environment. Gaalaas (1947), in a study of Jersey cows, found that the heat-tolerance coefficient was a reasonably stable individual characteristic at ages of 4 years and above, but not at 2 or 3 years of age. Seath (1947) concluded that body temperature appears to be a safer measuring stick for heat-tolerance than does respiration rate.

Lee and Robinson (1941) found that the sheep is outstanding among domestic animals in tolerating hot atmospheres, withstanding for 7 hours a temperature of $110^{\circ} \mathrm{F}$. with 65 per cent humidity. Lee, Robinson and Hines (1941) concluded that the tolerance of the rabbit resembles that of the fowl and that seasonal variations were complex and important. Robinson and Lee $(1941 \mathrm{a})$ found that the cat shows far less reaction to heat than the fowl, rabbit or pig. Temperatures of $105^{\circ} \mathrm{F}$. cannot be tolerated if the humidity is above 65 per cent. The same authors $(1941 \mathrm{~b})$ found that the tolerance of the dog to hot 
atmospheres is slightly greater than that of the cat. The effect of humidity was marked. They also found (1941 c) that the toleranoe of the pig for hot atmospheres resembles that of the fowl and the rabbit. Humidity was important at high temperatures but not at intermediate temperatures. Unlike the fowl and the rabbit, the pig's reactions to heat was noted to include a definite rise in pulse rate.

Marshal (1937) stated that Southdown ewes and red deer transported from the northern hemisphere to Australia, South Africa and the Argentine reverse their breeding season in about two years to conform with the conditions in the new habitat. New Zealand kinds introduced into England make the reverse adjustment in the same time. Similar adjustments are made by fallow deer, moose, wapiti and chamois introduced into New Zealand. Parakeets from Southern and Central Australia adjust themselves to English conditions, but those from Northern Australia retain their original breeding season.

Asmundson and Lloyd (1936) concluded that lower outside temperatures, particularly during the first few weeks, appeared to result in increased rate of growth of turkeys. Humidity did not apparently affected growth although continuous rain retarded growth.

Yeates, Lee and Hines (1941) found that a rectal temperature of $113^{\circ} \mathrm{F}$. is the highest the fowl can reach before developing heat stroke. White Leghorns can withstand heat better than Australorps. Barott and Pringle (1941), in a study of metabolic rate of the Rhode Island Red hen, for a temperature range of $50^{\circ}$ to $95^{\circ} \mathrm{F}$., found that a point of flexure occurs at $78^{\circ} \mathrm{F}$. They concluded that this is the temperature of minimum metabolism of the hen. The maximum metabolism occurred at $61^{\circ} \mathrm{F}$., at which temperature there was also a point of flexure. The rate of elimination of respiratory water was approximately constant between $65^{\circ}$ and $75^{\circ} \mathrm{F}$. The rate decreased considerbly between $60^{\circ}$ and $50^{\circ} \mathrm{F}$. The rate at $90^{\circ} \mathrm{F}$. was three times that at $80^{\circ} \mathrm{F}$. This was due to the large amount of air inhaled and exhaled for cooling at the high temperature. It was found that hens at a given temperature would survive at the lower humidities but would die when the humidity was increased. Bennion and Warren (1933) found that extremely high or low temperatures were followed by a decline in production; birds were more sensitive to sudden temperature changes. They also stated that in comparing egg size of birds from different parts 
of the United States, the temperature and its effects on egg size should be taken into consideration. They found that the mean weekly egg weight when compared with the mean maximum weekly temperature showed a sharp decline when the temperature was above $85^{\circ} \mathrm{F}$. The mean daily egg size of birds placed under controlled temperature was reduced from 15 to 20 per cent by application of high temperatures. The egg size declined much more rapidly under high temperature than it increased when the temperature was lowered. All components of the egg decreased under high temperature. The shell and albumen decreased considerably more than the yolk in proportion to their weight, which indicates that the oviduct is more sensitive than the ovary to high temperatures. Warren (1939) secured data on egg size from 11 localities in latitudes extending from the Equator to as far north as Scotland and concluded that excessively low temperatures seemed to have no effect on egg size, but after the daily maximum temperatures exceeded $70^{\circ} \mathrm{F}$. for a period of a few days, egg size fluctuations usually showed a close correlation with those of temperature. Lorenz and Almquist (1936) found evidence of a decrease in egg weight proportional to the increase in temperature between $40^{\circ}$ and $90^{\circ}$. Burrows and Byerly (1938) found that temperatures above $90^{\circ} \mathrm{F}$. was one of the factors that increased broodiness. Hays and Sanborn (1939) found that fertility in Rhode Island Red females varied with the temperature. As the temperature rose from, on the average, about $16^{\circ} \mathrm{F}$. to $46^{\circ} \mathrm{F}$. the fertility increased. However, Lamoreux (1943) found in White Leghorns no relationship between outside mean temperature and the proportions of eggs laid that were infertile. Mean weekly temperatures ranged from $22.9^{\circ} \mathrm{F}$. to $50.1^{\circ} \mathrm{F}$. In both of these studies the highest temperature tested was $50.1^{\circ} \mathrm{F}$. Kempster (1938), at Missouri, found that high maximum temperature that prevails during the summer retards the growth of pullets.

Warren (1930) found that disturbances that are sufficient to cause a decrease in the daily production of a group of White Leghorn pullets affect the rhythm of egg production. Bissonnette (1933) pointed out that in other birds sexual cycles are directly modifiable by changes in the daily exposure to light. French (1940) found that there appeared to be some relationship between hours of sunlight and egg production but the relationship to temperature was not so definite. Resananda, 
(1924) in a study of the best season for hatching eggs in the Philippines using eggs from several imported and Asiatic native breeds concluded that humidity and wind velocity had little effect. Wetham (1933) stated that the natural variation in daily light period at different latitudes has been used to study the effect of light on egg production throughout the world. There was a decided apparent correlation between egg production and the hours of daylight but the egg production curve precedes that of the light. It appeared that, where the hours of daylight are distributed more evenly throughout the year, the egg production is more evenly distributed throughout the year. Mann (1941) reported that the wet season in Malaya causes a decreased fecundity in Rhode Island Reds, increases incidence of the molt, and increases mortality. Hutt (1938) reported that during six days of heat at Ithaca, New York, when maximum temperatures reached 101,103 , and $102^{\circ} \mathrm{F}$. on three successive days, the deaths from heat prostration were 1.79 per cent in White Leghorns, 5.26 per cent in Rhode Island Reds, and 5.16 per cent in Barred Rocks. He concluded that the genetic constitution of the White Leghorn appears to give that breed more control over its thermo-regulatory processes than is available to the other breeds compared with it.

The evidence on effect of high temperature and especially high humidity as reported in humans, cattle, other animals and poultry indicates that the physiological response of animals and poultry to tropical and subtropical climates is different to that of temperate and cold climates.

It is probable that different standard breeds of poultry may react differently in adaptability to the climate and general environment of Puerto Rico. Many workers have found definite differences between breeds in response to certain stimuli under certain specific conditions. Taylor and Martin (1928) concluded that their Barred Rocks strain laid eggs with a significantly lower per cent of shell than a strain of White Leghorns. Morgan (1932) found that the Barred Plymouth Rock eggs require less weight to crush the shells than the White Leghorns. Hyre and Hall (1932) stated that hatching power seems to be more constant in the Single Comb White Leghorns studied than in the heavy breeds. Harris and Boughton (1928) found that the Rhode Island Red breed shows a somewhat higher death rate 
than the White Leghorn breed although that conclusion was questioned by Dudley, (1928). Lambert (1935) stated that heritable differences in resistance to infectious diseases exist and that non-infectious diseases are largely, in most cases, a genetic problem. Longevity and strong constitution were considered as inborn traits of certain families and strains. Roberts and Card (1926) concluded that it may be possible to establish a strain of fowls that would be highly resistant to infection with S. pullora. Serfontine and Payne, cited by Jull (1946), ob- served that White Leghorns were more resistant than heavier breeds to Perosis or slipped tendons. Pappenheimer, Dunn and Cone, cited by Jull (1946), stated that their observations indicated a very significant breed or variety difference in susceptibility to paralysis. Lamoreux and Hutt (1939) found that ability of White Leghorn chicks to survive on a diet deficient, or lacking, in vitamin $B_{1}$ was greater than that of the Rhode Island Reds. Hutt (1935) demonstrated a breed difference between White Leghorns and Rhode Island Reds in the rate at which body temperature rises during the first nine days after hatching.

Crossing breeds for the purpose of developing better breeds for tropical climates is being done with cattle and other animals in different parts of the world. Bray (1932) found that a Brahman cross on native and grade beef cattle in southern Louisiana was valuable because it withstands heat and is less affected by flies, mosquitoes and external and internal parasites. Also this cross was observed to make good gains on grass alone. Rhoad (1938), in a study of the response of pure-bred Bos taurus and Bos indicus cattle and their crossbred types to certain conditions of the environment, found that high atmospheric temperatures and humidity influence, in unlike manner, the respiration rate and body temperature of typical Bos taurus and Bos indicus cattle. The same author (1940) determined that the purebred and three-quarter bred Aberdeen Angus are not physiologically adapted to the high temperature and intense solar radiations characteristic of tropical climates. On the other hand, he stated that the efficiency with which the purebred and half-bred Brahman regulates body temperature in the same environment is evidence that tropical climatic conditions are within the range of neutrality for these cattle. This indicates, therefore, that these cattle are physiologically adapted to a tropical 
environment. According to Rhoad, the differences in the physiological responses of these cattle to tropical climatic conditions are genetic in origin. Rhoad $(1935, \mathrm{p} .214)$ stated:

The general conclusion reached in all parts of the tropical world, however, is that the permanent solution of the farm dairy problem is not devising new ways of managing the old established breeds, but rather the development of new breeds using the native type as foundation stock.

The same author (1941, p. 512) stated that there are distinct differences between species and breeds in their ability to withstand climatic conditions. He said,

It has been clearly demonstrated in recent years, that the lack of adaptability of certain types of animals to tropical climatic conditions, as evidenced by discomfort, low production, and frequently degeneration in type, can best be overcome by breeding.

Crossbreeding of Brahman with standard beef breeds for resistance to subtropical climatic conditions has been, according to Rhoad, a general practice in the Gulf-coast region for more than a generation. From one of these crosses, the Shorthorn $x$ Brahman, there has evolved the first strictly American breed of beef cattle, the Santa Gertrudis, developed by the Klebergs of the King Ranch, Kingsville, Texas. Improved dairy types of cattle adaptable to tropical and subtropical climatic conditions are being developed in India with pure Brahman (Zebu) stock, while in Brazil, Jamaica, and the Philippines new BrahmanEuropean crossbred types are appearing. In the Philippines a new breed of swine, the Berkjala, a cross between the Berkshire and the native Jalajala, is being developed as a lard type hog adapted to tropical climatic conditions. At the Agricultural Experiment Station of the University of Puerto Rico breeding projects are now in progress for the development of better adapted breeds of cattle, swine, goats, and poultry.

Results obtained in crossing poultry breeds have been reported by some workers in the United States.

From crosses between Single Comb White Leghorns and Jersey Black Giants Warren $(1926,1927)$ found that the $F_{1}$ crossbreds hatch better, grow faster and lay better than do the parental breeds. They also showed a lower mortality. The viability of the crossbred chicks to three weeks of age was superior to that of the White Leghorn and Jersey Black Giant purebred chicks. The adult size of the crossbreds was inter- 
mediate between that of the two breeds crossed. Byerly, Knox and Jull (1934) stated that crossing breeds is likely to increase hatchability by decreasing mortality during the third week of incubation. Knox, cited by Jull (1946), observed that crossbred progeny obtained from several different crosses, on the average, had 13.3 per cent better viability than purebred progeny, viability being measured from hatching time to the end of the first laying year. Jull (1946, p. 227) summarized the effect of crossing breeds on body size as follows :

In practically all cases in which there was not an extreme difference in size between the parental breeds that were used in the original cross, the size of the $F_{1}$ progeny was about midway between the parental breeds or slightly nearer the larger breed. In those cases in which there were extreme differences in size between the parental breeds crossed, as in the case of the Barred Plymouth Rock x Rose-Comb Bantam matings made by Jull and Quinn (1931) and the light Brahma x Golden Sebright Bantam matings made by $\mathrm{Maw}$ (1935), the size of the $\mathrm{F}_{1}$ progeny was slightly nearer the smaller sized breed.

In summary, the literature cited indicates that the high temperatures of tropical and subtropical regions lower the productivity of non-adapted animals including poultry, by reduction of the metabolic rate, and by other unknown causes. High humidity may aggravate the detrimental effect of high temperature on productivity. In poultry, egg size, broodiness, fertility, growth, hatchability, and egg production may be influenced. The literature cited also indicates that it is possible to find a differential response of the different breeds of poultry to the tropical environment. Crossing standard breeds with native stocks appear to be a definite possibility for obtaining adaptability together with relatively high productivity.

\section{Methods of Procedure}

This study includes data collected from July, 1946 to June, 1948. The standard breeds were the New Hampshire and the Single Comb White Leghorn, that is, a representative each of the dual purpose and light egg types. These birds came from stock originally imported from the United States in 1940. Since that time they have been bred without any special selection.

The Native flock was obtained through purchases of birds throughout different parts of the Island in an attempt to make it a representative sample of the Island's stock. 
Crossing the White Leghorn and the New Hampshire with the Native was started in 1945 but the numbers have been small up to 1947. Even then all crosses of White Leghorn $x$ Native were combined and treated collectively. The same was done with all crosses of New Hampshire $x$ Native.

The eggs from the three principal breeds and from the crosses between them were all hatched in the same incubator; the same feed was given all the birds, and they were reared in the same brooder house. The laying hens were confined to wire floor pens, $20^{\prime} \times 10^{\prime}$, exactly alike and close together in an area of less than one acre. The same men took care of all the breeds.

In 1946 the hatching season extended from February 6 to June 6 for a period of four months. Chicks were hatched, every week during that time but for statistical analysis they were divided, according to the date hatched, into six groups of three consecutive hatches per group. In 1947 the hatching season extended for a period of two months, from February 6 to April 4. Birds were again grouped according to date of hatch into groups, with three consecutive hatches per group. In 1947 there were only three groups.

A considerable amount of data was recorded on these birds but this study will be concerned only with egg production, sexual maturity, egg weight, body weight up to four months of age, and mortality. Except for mortality, the data in 1946 included 67 White Leghorn birds, 98 New Hampshire, and 39 Natives. In 1947, there were 68 White Leghorns, 165 New Hampshires, 33 Native, 69 White Legborn $x$ Native, and 55 New Hampshire $x$ Native. Chick mortality was recorded in 1946 on 145 New Hampshire chicks, 135 White Leghorns, and 121 Natives. For 1947 there were 616 New Hampshire chicks, 220 White Leghorns, 288 Natives, 493 White Lebhorn x Natives, and 665 New Hampshire $\mathrm{x}$ Natives. Laying flock mortality was recorded in 1946 on 137 New Hampshire hens, 91 White Leghorns, and 58 Natives. For 1947 there were 219 New Hampshires, 64 White Leghorns, 44 Natives, 122 White Leghorn $\mathrm{x}$ Natives, and 111 New Hampshires $x$ Natives.

Egg production was measured on the basis of the number of eggs laid for the first 120 days of laying. Harris (1922), Thompson (1933), and many other workers, have shown that rate of production is a good criterion of total first year production. 
Sexual maturity was measured as the age in days of the bird at first egg.

Egg weight per individual hen was measured in ounces per dozen eggs equivalent for the first 120 days of laying. Jull and Godfrey (1933), and other workers, have demonstrated the reliability of short periods egg weight records for estimating mean annual egg weight.

Body weight was taken in pounds at the end of the first, second, third, and fourth month of age. Funk, Knandel, and Callenbach (1930) found that initial chick weights and subsequent weights showed little correlation but that weights at $4,8,16$, and 24 weeks show a high positive correlation with each other.

Chick mortality was measured as the percentage of chicks dead from hatching to one month of age. Dunn (1922) measured chick mortality to three weeks after hatching and stated that it seems probable that early chick mortality is the result of general constitutional weakness.

Laying flock mortality was recorded from the start of laying until each bird completed one year of production. Pearl (1923) stated that the individual which is structurally and functionally of superior constitution will, in the long run, exhibit a relatively high degree of longevity.

The method of fitting constants as given in Snedecor's text (1946) was used for analysis of variance of egg production, sexual maturity, egg weight and body weight. The t tests were carried out as given by Goulden (1939). The method of Patterson (1946) was also tried for the evaluation of interactions. Differences in mortality were tested through Chi-square analysis.

In all tables one asterisk $\left({ }^{*}\right)$ and two asterisks $(* *)$ represent statistical significance at the $\mathrm{P}<.05$ and $\mathrm{P}<.01$ levels of probability, respectively.

\section{EXPERIMENTAL RESULTS}

Comparison of White Leghorn, New Hampshire, and Native Birds Egg production

In table 1 the average production of the three breeds for the first 120 days of laying during 1946 and 1947 is presented. The analysis of variance of these data is also given in this table. 
The average egg production of the imported breeds is shown to be very similar with 45.5 eggs for the Leghorns and 47.6 eggs for the New Hampshires. However, the production of the Natives was only 26.4 eggs which is significantly lower than that of the other two breeds. This difference is shown for each of the two years.

In 1946 differences between hatches were significant. Birds hatched from February 6 to March 14 were the poorest layers and those hatched from March 21 to April 25 were the best layers. Interaction was, however, negligible, indicating that the date of hatch affected the production of the different breeds proportionally. The shortening of the hatching season during 1947, from four to two months, was effective in eliminating any important difference due to hatch. In tables 2 and 3 the effect of date of hatch on production during 1946 and 1947, respectively, is shown. The analyses of variance of these data are also given in the tables.

TABLE No. 1

MEAN EGG PRODUCTION OF WHITE LEGHORNS, NEW HA MPSHIRES, AND NATIVES DURING 1946 AND 1947

\begin{tabular}{|c|c|c|c|c|c|c|}
\hline \multirow{2}{*}{ BREED } & \multicolumn{6}{|c|}{ Mean Egg Production } \\
\hline & \multicolumn{2}{|c|}{1946} & \multicolumn{2}{|c|}{1947} & \multicolumn{2}{|c|}{$\underset{\text { Years }}{\text { Combined }}$} \\
\hline 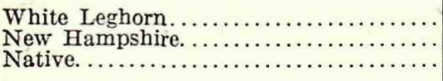 & $\begin{array}{l}(67)^{1} \\
(98)^{2} \\
(39)\end{array}$ & $\begin{array}{l}45.4 \\
47.5 \\
30.9\end{array}$ & $\begin{array}{r}(68) \\
(165) \\
(33)\end{array}$ & $\begin{array}{l}45.7 \\
47.8 \\
21.2\end{array}$ & $\begin{array}{r}(135) \\
(263) \\
(72)\end{array}$ & $\begin{array}{l}45.5 \\
47.6 \\
26.4\end{array}$ \\
\hline Unweighted mean ................. & & 41.3 & & 38.2 & & 39.8 \\
\hline
\end{tabular}

\begin{tabular}{|c|c|c|c|}
\hline . & \multicolumn{3}{|c|}{ ANALYSIS OF VARIANCE } \\
\hline$\cdot$ & $\mathrm{d} / \mathrm{f}$ & $\begin{array}{l}\text { Sums of } \\
\text { Squares }\end{array}$ & $\begin{array}{c}\text { Mean } \\
\text { Square }\end{array}$ \\
\hline 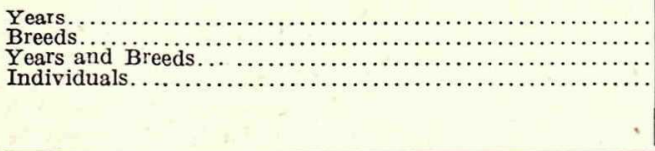 & $\begin{array}{r}1 \\
2 \\
2 \\
464\end{array}$ & $\begin{array}{r}176.51 \\
26,207.34 \\
1,503.42 \\
181,195.69\end{array}$ & $\begin{array}{l}176.51 \\
13,022.55^{* *} \\
\quad 751.71 \\
\quad 390.51 \\
b=19.75\end{array}$ \\
\hline
\end{tabular}

1 Figures in parenthesis are number of birds. 
TABLE No. 2

MEAN EGG PRODUCTION BY HATCHES OF WHITE LEGHORNS NEW HAMPSHIRES, AND NATIVES DURING 1946

\begin{tabular}{|c|c|c|c|c|c|c|}
\hline \multirow{2}{*}{ HATCH } & \multicolumn{6}{|c|}{ Mean EgG Production } \\
\hline & \multicolumn{2}{|c|}{$\begin{array}{l}\text { White } \\
\text { Leghorn }\end{array}$} & \multicolumn{2}{|c|}{$\begin{array}{c}\text { New } \\
\text { Hampshi־e }\end{array}$} & \multicolumn{2}{|c|}{ Native } \\
\hline 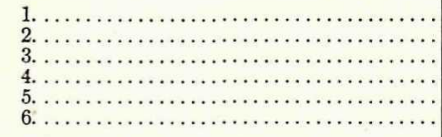 & $\begin{array}{l}(14)^{1} \\
(7) \\
(14) \\
(19) \\
(7) \\
(6)\end{array}$ & $\begin{array}{l}41.1 \\
36.6 \\
38.2 \\
55.1 \\
46.0 \\
50.7\end{array}$ & $\begin{array}{r}(13) \\
(16) \\
(21) \\
(32) \\
(6) \\
(10)\end{array}$ & $\begin{array}{l}23.9 \\
46.4 \\
49.8 \\
53.8 \\
\text { 49. } \\
53.3\end{array}$ & $\begin{array}{r}(5) \\
(3) \\
(8) \\
(13) \\
(4) \\
(6)\end{array}$ & $\begin{array}{l}23.2 \\
27.0 \\
40.8 \\
31.8 \\
27.5 \\
26.2\end{array}$ \\
\hline A verage . . . . . . . . & $(67)$ & 45.4 & $(98)$ & 47.5 & $(39)$ & 30.9 \\
\hline
\end{tabular}

\begin{tabular}{|c|c|c|c|}
\hline & \multicolumn{3}{|c|}{ ANALYSIS OF VARIANCE } \\
\hline & $\mathrm{d} / \mathrm{f}$ & $\begin{array}{l}\text { Sums of } \\
\text { Squares }\end{array}$ & $\begin{array}{c}\text { Mean } \\
\text { Square }\end{array}$ \\
\hline 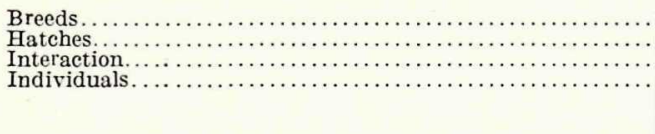 & $\begin{array}{r}2 \\
5 \\
10 \\
186\end{array}$ & $\begin{array}{r}8,789.18 \\
8,164.79 \\
5,586.05 \\
62,209.89\end{array}$ & $\begin{array}{c}4,394.59^{* *} \\
1,632.96^{* *} \\
558.61 \\
334.46 \\
b=18.30\end{array}$ \\
\hline
\end{tabular}

1 Figures in parenthesis are number of birds.

TABLE No. 3

MEAN EGG PRODUCTION BY HATCHES OF WHITE LEGHORNS, NEW HAMPSHIRES, AND NATIVES DURING 1947

\begin{tabular}{|c|c|c|c|c|c|c|}
\hline \multirow[b]{2}{*}{ HATCH } & \multicolumn{6}{|c|}{ Mení Egg Production } \\
\hline & \multicolumn{2}{|c|}{$\begin{array}{l}\text { White } \\
\text { Leghorn }\end{array}$} & \multicolumn{2}{|c|}{$\begin{array}{c}\text { New } \\
\text { Hampshire }\end{array}$} & \multicolumn{2}{|c|}{ Native } \\
\hline 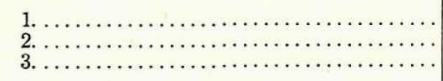 & $\begin{array}{l}(11)^{1} \\
(25)^{1} \\
(32)\end{array}$ & $\begin{array}{l}\text { 43. } 6 \\
\text { 43. } 0 \\
\text { 48. } 7\end{array}$ & $\begin{array}{l}(34) \\
(39) \\
(92)\end{array}$ & $\begin{array}{l}49.0 \\
42.3 \\
49.6\end{array}$ & $\begin{array}{l}(10) \\
(13) \\
(10)\end{array}$ & $\begin{array}{l}17.5 \\
25.7 \\
19.0\end{array}$ \\
\hline A verage....... & $(68)$ & 45.7 & (165) & 47.8 & (33) & 21.2 \\
\hline
\end{tabular}

\begin{tabular}{|c|c|c|c|}
\hline & \multicolumn{3}{|c|}{ ANALYSIS OF VARIANCE } \\
\hline & $\mathrm{d} / \mathrm{f}$ & $\begin{array}{l}\text { Sums of } \\
\text { Squares }\end{array}$ & $\begin{array}{l}\text { Mean } \\
\text { Square }\end{array}$ \\
\hline 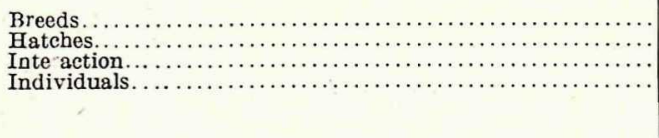 & $\begin{array}{r}2 \\
2 \\
4 \\
257\end{array}$ & $\begin{array}{r}17,969.54 \\
1,150.45 \\
1,352.52 \\
102,731.99\end{array}$ & $\begin{array}{c}8,984.77^{* *} \\
575.22 \\
338.13 \\
399.74 \\
b=19.99\end{array}$ \\
\hline
\end{tabular}

1 Figures in parenthesis are number of birds. 


\section{Sexual maturity}

In table 4 the average sexual maturity (age in days at first egg) of the three breeds during 1946 and 1947 is presented together with the analysis of variance.

The variation in the sexual maturity of the Native birds was considerable from 1946 to 1947 . They were as late maturing as the New Hampshires in 1946 and as early as the White Leghorns in 1947. The White Leghorns had earlier sexual maturity than the New Hampshires in both years.

The standard deviation in sexual maturity during 1946 were 13,38 , and 44 days, respectively, for the White Leghorns, New Hampshires, and Natives. In 1947 it was 23, 41, and 52 days, respectively. There was less variation within the Leghorn birds than within the other breeds in respect to this trait. The wide variation within the New Hampshires and the Natives may account in part for the fairly large variance obtained from the residual individuals.

The date of hatch affected the sexual maturity of the birds of the different breeds differently during 1946. Earlier hatched birds of the White Leghorn and New Hampshire breeds, hatched during February 6 to February 21, had the earliest sexual maturity. The latest maturing birds of the New Hampshire breed were those hatched from May 2 to June 6 and of the White Leghorn, those hatched from May 23 to June 6. The earliest maturing Native pullets were those hatched from May 23 to June 6 and from February 6 to February 21. The latest maturing were those hatched from March 21 to April 4 . Table 5 shows the effect of date of hatch on sexual maturity during 1946.

The shortening of the hatching season in 1947 was effective in eliminating the differences due to interaction of breeds $\mathrm{x}$ hatches. However, the tendency of the birds of all breeds was to mature earlier when hatched earlier. In table 6 the effect of date of hatch on sexual maturity during 1947 is shown together with the analysis of variance.

\section{Egg weight}

The average egg weight of the three breeds and the corresponding analysis of variance is given in table 7 . 
TABLE No. 4

AGE AT FIRST EGG OF WHITE LEGHORNS, NEW HAMPSHIRES, AND NATIVES

\begin{tabular}{|c|c|c|c|c|c|c|}
\hline \multirow{2}{*}{ BREED } & \multicolumn{6}{|c|}{ AgE at First EGG (days) } \\
\hline & \multicolumn{2}{|c|}{1946} & \multicolumn{2}{|c|}{1947} & \multicolumn{2}{|c|}{$\underset{\text { Years }}{\text { Combined }}$} \\
\hline 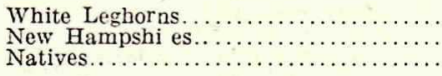 & $\begin{array}{l}(67)^{1} \\
(98)^{1} \\
(39)\end{array}$ & $\begin{array}{l}187 \\
220 \\
234\end{array}$ & $\begin{array}{r}(68) \\
(165) \\
(33)\end{array}$ & $\begin{array}{l}192 \\
225 \\
195\end{array}$ & $\begin{array}{r}(135) \\
(263) \\
(72)\end{array}$ & $\begin{array}{l}190 \\
223 \\
216\end{array}$ \\
\hline Unweighted mean ............... & & 214 & & 204 & & 210 \\
\hline
\end{tabular}

\begin{tabular}{|c|c|c|c|}
\hline \multirow{3}{*}{ 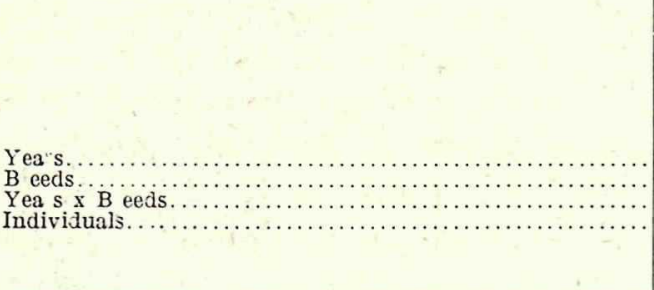 } & \multicolumn{3}{|c|}{ ANALYSIS OF VARIANCE } \\
\hline & $d / f$ & $\begin{array}{l}\text { Sums of } \\
\text { Squares }\end{array}$ & $\begin{array}{c}\text { Mean } \\
\text { Squa"e }\end{array}$ \\
\hline & $\begin{array}{r}1 \\
2 \\
2 \\
464\end{array}$ & $\begin{array}{r}393.41 \\
99,291.99 \\
29,638.53 \\
634,218.40\end{array}$ & $\begin{array}{l}393.41 \\
49,646.00^{* *} \\
14,819.27^{* *} \\
1,366.85 \\
b=36.97\end{array}$ \\
\hline
\end{tabular}

1 Figures in parenthesis are number of birds.

TABLE No. 5

AGE AT FIRST EGG BY HATCHES OF WHITE LEGHORNS, NEW HAMPSHIRES, AND NATIVES DURING 1916

\begin{tabular}{|c|c|c|c|c|c|c|}
\hline \multirow{2}{*}{ HATCH } & \multicolumn{6}{|c|}{ AgE at First EGG (days) } \\
\hline & \multicolumn{2}{|c|}{$\begin{array}{l}\text { White } \\
\text { Leghorn }\end{array}$} & \multicolumn{2}{|c|}{$\begin{array}{c}\text { New } \\
\text { Hampshire }\end{array}$} & \multicolumn{2}{|c|}{ Native } \\
\hline 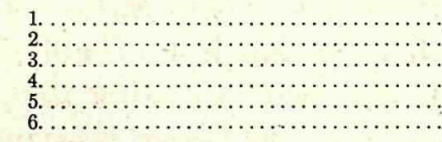 & $\begin{array}{l}(14)^{1} \\
(7) \\
(14) \\
(19) \\
(7) \\
(6)\end{array}$ & $\begin{array}{l}175 \\
197 \\
186 \\
185 \\
190 \\
213\end{array}$ & $\begin{array}{r}(13) \\
(16) \\
(21) \\
(32) \\
(6) \\
(10)\end{array}$ & $\begin{array}{l}187 \\
217 \\
210 \\
224 \\
262 \\
245\end{array}$ & $\begin{array}{r}(5) \\
(3) \\
(8) \\
(13) \\
(4) \\
(6)\end{array}$ & $\begin{array}{l}211 \\
222 \\
265 \\
242 \\
236 \\
202\end{array}$ \\
\hline Average........... & (67) & 187 & (98) & 220 & (39) & 234 \\
\hline
\end{tabular}

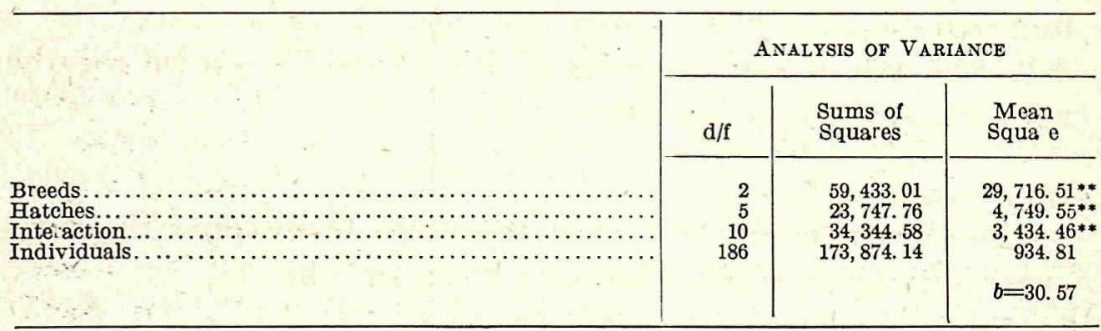

Figures in parenthesis are number of birds. 
TABLE No. 6

AGE AT FIRST EGG BY HATCHES OF WHITE LEGHORNS, NEW HAMPSHIRES, AND NATIVES DURING 1917

\begin{tabular}{|c|c|c|c|c|c|c|}
\hline \multirow[b]{2}{*}{ H $\triangle T C H$} & \multicolumn{6}{|c|}{ AgE at First EgG } \\
\hline & \multicolumn{2}{|c|}{$\begin{array}{l}\text { White } \\
\text { Leghorn }\end{array}$} & \multicolumn{2}{|c|}{$\begin{array}{c}\text { New } \\
\text { Hampshire }\end{array}$} & \multicolumn{2}{|c|}{ Native } \\
\hline 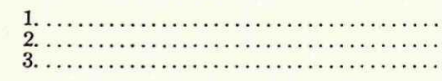 & $\begin{array}{l}(11)^{1} \\
(25)^{1} \\
(32)\end{array}$ & $\begin{array}{l}184 \\
189 \\
198\end{array}$ & $\begin{array}{l}(34) \\
(39) \\
(92)\end{array}$ & $\begin{array}{l}218 \\
218 \\
230\end{array}$ & $\begin{array}{l}(10) \\
(13) \\
(10)\end{array}$ & $\begin{array}{l}183 \\
191 \\
212\end{array}$ \\
\hline 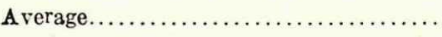 & $(68)$ & 192 & (165) & 225 & $(33)$ & 195 \\
\hline
\end{tabular}

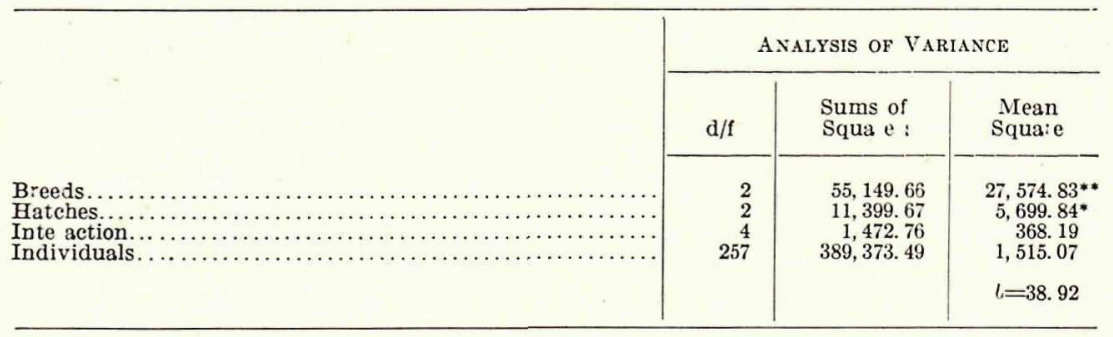

1 Figures in parenthesis are number of birds.

Egg size was smaller for all the breeds during 1947 than during 1946. As a breed the New Hampshires had the largest eggs while the White Leghorn eggs were larger than the Native eggs.

There were significant differences between the hatches in both years but all breeds were affected proportionally by the date of hatch. During 1946 egg weight fluctuated up and down throughout the hatching season. During 1947 the tendency of the birds of all breeds was to have larger egg weight when hatched latest. This may be explained by the fact that late hatched birds in 1947 matured later and thus were older when they started laying.

The effect of date of hatch on egg weight during 1946 and 1947 is shown in tables 8 and 9 respectively.

The correlation between sexual maturity and egg weight can be observed easily by comparing table 8 with table 5 . The earlier maturing birds of the White Leghorn breed were found in groups 1 and 4 where the smallest egg weights were observed. The latest maturing birds of the same breed belonged to group 6 where the heaviest eggs were found. Groups 2, 3 and 5 were intermediate in maturity and egg size. The correlation coefficient was .413 , with 65 degrees of freedom. 
The earliest maturing New Hampshires were in groups 1 and 3. The same birds laid the smallest eggs. For the same breed groups 2, 4 and 6 , and 5 in table 5 closely correspond to the same groups in table 8 . The correlation coefficient was .437 , with 96 degrees of freedom.

The earliest maturing Natives and their smallest egg weights belonged to groups 1 and 6 . The latest maturing birds were in groups 3, 4, and 5 where the heaviest eggs were found. Group 2 , intermediate in maturity, was also intermediate in egg weight. The correlation coefficient was .496, with 37 degrees of freedom.

TABLE NO. 7

EGG WEIGHT OF WHITE LEGHORNS, NEW HAMPSHIRES, AND NATIVES

\begin{tabular}{|c|c|c|c|c|c|c|}
\hline \multirow{2}{*}{ BREED } & \multicolumn{6}{|c|}{ MEAN EgG WeIGHT (ounces per dozen) } \\
\hline & \multicolumn{2}{|c|}{1946} & \multicolumn{2}{|c|}{1947} & \multicolumn{2}{|c|}{$\underset{\text { Yea's }}{\text { Combined }}$} \\
\hline 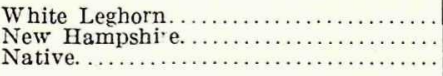 & $\begin{array}{l}(67)^{1} \\
(98)^{2} \\
(39)\end{array}$ & $\begin{array}{l}20.0 \\
21.1 \\
17.9\end{array}$ & $\begin{array}{r}(68) \\
(165) \\
(33)\end{array}$ & $\begin{array}{l}19.3 \\
20.9 \\
16.9\end{array}$ & $\begin{array}{r}(135) \\
(263) \\
(72)\end{array}$ & $\begin{array}{l}\text { 19. } 6 \\
20.9 \\
17.4\end{array}$ \\
\hline
\end{tabular}

\begin{tabular}{|c|c|c|c|}
\hline & \multicolumn{3}{|c|}{ ANALYSIS OF VARIANCE } \\
\hline & $\mathrm{d} / \mathrm{f}$ & $\begin{array}{l}\text { Sums of } \\
\text { Squares }\end{array}$ & $\begin{array}{l}\text { Mean } \\
\text { Square }\end{array}$ \\
\hline 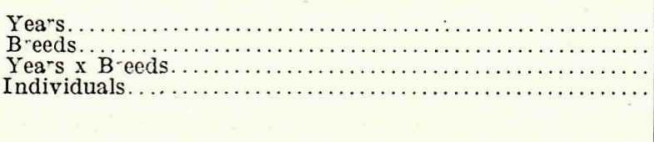 & $\begin{array}{r}1 \\
2 \\
2 \\
464\end{array}$ & $\begin{array}{r}24.42 \\
750.45 \\
9.86 \\
965.87\end{array}$ & $\begin{array}{l}\text { 24. } 42^{* *} \\
375.22^{* *} \\
\quad 4.93 \\
2.08 \\
b=1.44\end{array}$ \\
\hline
\end{tabular}

1 Figures in parenthesis are number of bi-ds.

TABle No. 8

EGG WEIGHT BY HATCHES OF WHITE LEGHORNS, NEW HAMPSHIRES, AND NATIVES DURING 1946

\begin{tabular}{|c|c|c|c|c|c|c|}
\hline \multirow{2}{*}{ НАTCH } & \multicolumn{6}{|c|}{ MEAN EgG Weight (ounces per dozen) } \\
\hline & \multicolumn{2}{|c|}{$\begin{array}{l}\text { White } \\
\text { Legho:n }\end{array}$} & \multicolumn{2}{|c|}{$\begin{array}{l}\text { New } \\
\text { Hampshires }\end{array}$} & \multicolumn{2}{|c|}{ Native } \\
\hline 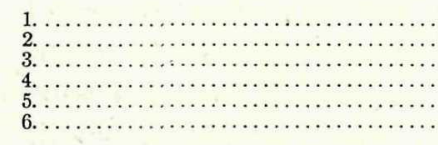 & $\begin{array}{l}(14)^{1} \\
(7) \\
(14) \\
(19) \\
(7) \\
(6)\end{array}$ & $\begin{array}{l}\text { 19. } 7 \\
20.2 \\
20.0 \\
19.7 \\
20.3 \\
21.0\end{array}$ & $\begin{array}{r}(13) \\
(16) \\
(21) \\
(32) \\
(6) \\
(10)\end{array}$ & $\begin{array}{l}20.3 \\
21.0 \\
20.5 \\
21.5 \\
22.4 \\
21.4\end{array}$ & $\begin{array}{r}(5) \\
\text { (3) } \\
(8) \\
(13) \\
(4) \\
(6)\end{array}$ & $\begin{array}{l}\text { 16. } 9 \\
\text { 17. } 7 \\
\text { 18. } 1 \\
13.2 \\
18.7 \\
17.2\end{array}$ \\
\hline A verage........... & $(67)$ & 20.0 & (98) & 21.1 & $(39)$ & 17. 9 \\
\hline
\end{tabular}




\begin{tabular}{|c|c|c|c|}
\hline+ & \multicolumn{3}{|c|}{ ANalysis of VARIANCE } \\
\hline 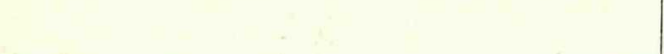 & $\mathrm{d} / \mathrm{f}$ & $\begin{array}{l}\text { Sums of } \\
\text { Squa-es }\end{array}$ & $\begin{array}{c}\text { Mean } \\
\text { Squa e }\end{array}$ \\
\hline 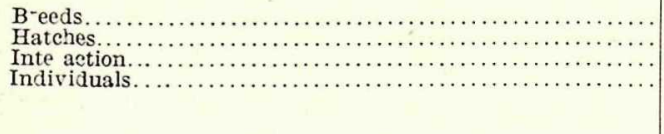 & $\begin{array}{r}2 \\
5 \\
10 \\
186\end{array}$ & $\begin{array}{r}314.99 \\
51.25 \\
256.10 \\
\end{array}$ & $\begin{array}{c}157.49^{* *} \\
10.25^{* *} \\
.55 \\
1.38 \\
t=1.18\end{array}$ \\
\hline
\end{tabular}

1 Figures in parenthesis are numbe: of birds.

TABLE No. 9

EGG WEIGHT BY HATCHES OF WHITE LEGGORNS, NEW HAMPSHIRES, AND NATIVES DURING 1947

\begin{tabular}{|c|c|c|c|c|c|c|c|}
\hline \multirow{2}{*}{ HАтCH } & & \multicolumn{6}{|c|}{ MEan EgG Weight (ounces pe- d ze ) } \\
\hline & & & $\begin{array}{l}\text { hite } \\
\text { gho } n\end{array}$ & & $\begin{array}{l}\text { Jew } \\
\text { apshi e }\end{array}$ & & \\
\hline 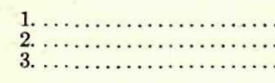 & 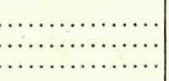 & $\begin{array}{l}(11)^{1} \\
(25)^{1} \\
(32)\end{array}$ & $\begin{array}{l}19.2 \\
19.2 \\
19.5\end{array}$ & $\begin{array}{l}(34) \\
(39) \\
(92)\end{array}$ & $\begin{array}{l}20.6 \\
20.5 \\
21.1\end{array}$ & $\begin{array}{l}(10) \\
(13) \\
(10)\end{array}$ & $\begin{array}{l}16.5 \\
16.5 \\
17.7\end{array}$ \\
\hline A verage $\ldots . . . .$. & & (68) & 19. 3 & (165) & 20.9 & (33) & 16. 9 \\
\hline
\end{tabular}

\begin{tabular}{|c|c|c|c|}
\hline \multirow[b]{2}{*}{ 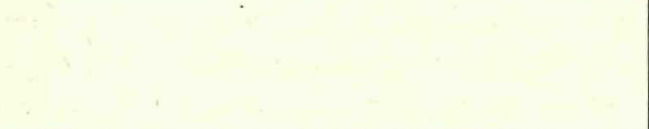 } & \multicolumn{3}{|c|}{ ANALYSIS OF VARIANCE } \\
\hline & $d / f$ & $\begin{array}{l}\text { Sums of } \\
\text { Squares }\end{array}$ & $\begin{array}{l}\text { Mean } \\
\text { Square }\end{array}$ \\
\hline 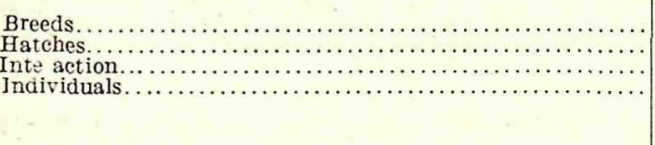 & $\begin{array}{r}2 \\
2 \\
4 \\
257\end{array}$ & $\begin{array}{r}426.82 \\
19.42 \\
4.66 \\
568.84\end{array}$ & $\begin{array}{l}213.41^{* *} \\
\quad 9.71^{* *} \\
\text { 1. } 17 \\
\text { 2. } 21 \\
t=1.49\end{array}$ \\
\hline
\end{tabular}

1 Figures in parenthesis are number of birds.

The correlation between sexual maturity and egg size can also be observed in the data for 1947 by comparing table 9 with table 6 . The earliest maturing birds of all the breeds laid the smallest eggs.

This correlation between maturity and egg weight is probably due to larger body size of the late maturing birds at the time of first egg. Although no data are available to substantiate this statement it seems to be warranted by results obtained by other workers (Jull, 1946).

Body weight

In table 10 the average body weight of the three breeds during 1947 for the first four months of age is presented. 
TABLE No. 10

BODY WEIGHT AND THE STANDARD DEVIATION OF W.EIGHTS OF WHITE LEGHORNS, NEW HAMSHIRES, AND NATIVES FOR 1947 AT FOUR DIFFEREN'T AGES

\begin{tabular}{|c|c|c|c|c|c|c|c|c|}
\hline \multirow[b]{2}{*}{ BREED } & & \multicolumn{3}{|c|}{ A GE IN Months } & \\
\hline & One & $\mathrm{S}$ & Tw & $\mathrm{S}$ & Three & $\mathrm{S}$ & Four & $\mathrm{S}$ \\
\hline & (lbs.) & & (lbs). & & (lbs.) & & (lbs.) & \\
\hline 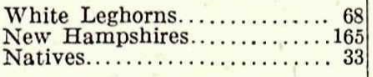 & $\begin{array}{l}.56 \\
.57 \\
.45\end{array}$ & $\begin{array}{l}.09 \\
.06 \\
.07\end{array}$ & $\begin{array}{l}1.40 \\
1.45 \\
1.11\end{array}$ & $\begin{array}{l}.19 \\
.20 \\
.15\end{array}$ & $\begin{array}{l}2.31 \\
2.49 \\
1.64\end{array}$ & $\begin{array}{l}.28 \\
.39 \\
.26\end{array}$ & $\begin{array}{l}\text { 3. } 02 \\
\text { 3. } 21 \\
2.16\end{array}$ & $\begin{array}{l}.33 \\
.43 \\
.27\end{array}$ \\
\hline
\end{tabular}

There were no significant differences in weight between the White Leghorn and the New Hampshire birds at the end of the first and second month of age. However, at the end of the third and fourth month of age the New Hampshires weighed .18 and .19 pounds more, respectively, than the White Leghorns. The $t$ value obtained was 3.31 for the third month and 3.29 for the fourth month. The probability in both cases was less than .01 for 231 degrees of freedom. Both standard breeds were heavier than the Natives at the end of each of the four months. The White Lebhorns weighed $.11, .29, .67$, and .86 pounds more than the Natives at each of the four months. With 99 degrees of freedom the probability was less than .01 in all cases. The $t$ values obtained were 6.43 for the first month and $7.72,11.45$, and 12.91 for the other three successive months. The New Hampshires weighed $.12, .34, .85$, and 1.05 pounds more than the Natives at each of the four successive months. With 196 degrees of freedom the probability was also less than .01 in all cases. The $t$ values were 10.50 for the first month and 9.09, 11.91, and 13.39 for the following three successive months.

The variation in weight within the breeds increased constantly from the first to the fourth month of age. The widest variation was found within the New Hampshire at the end of the third and fourth month of age. The Natives varied less than the other breeds at the same ages.

The variation in weight within the breeds increased constantly from the first to the fourth month of age. The widest hatched birds of the White Leghorn and New Hampshire breeds had a tendency to weigh less than those hatched later whereas earlier hatched birds of the Native breed had a tendency to weigh more than those hatched later. The effect of date of hatch on body weight, however, disappeared after the first month of age. 
In table 11 the effect of the date of hatch on the body weight of the different breeds at the end of the first month of age is presented. The analysis of variance of these data is also shown in the table.

TABLE NO. 11

EFFECT OF DATE OF HATCH ON THE BODY WEIGHT OF WHITE LEGHORNS' NEW HAMPSHIRES, AND NATIVES AT THE END OF THE FIRST MONTH OF AGE

\begin{tabular}{|c|c|c|c|c|c|}
\hline \multirow{2}{*}{ НАтсH } & \multicolumn{5}{|c|}{ Weight IN POUNDS } \\
\hline & $\begin{array}{l}\text { White } \\
\text { Leghorn }\end{array}$ & \multicolumn{2}{|c|}{$\begin{array}{l}\text { New } \\
\text { Hampshi:e }\end{array}$} & \multicolumn{2}{|c|}{ Native } \\
\hline 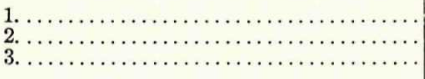 & $\begin{array}{l}(11)^{1} \\
(25)^{2} \\
(32)\end{array}$ & $\begin{array}{l}(34) \\
(39) \\
(92)\end{array}$ & $\begin{array}{l}.52 \\
.57 \\
.58\end{array}$ & $\begin{array}{l}(10) \\
(13) \\
(10)\end{array}$ & $\begin{array}{l}.47 \\
.45 \\
.43\end{array}$ \\
\hline
\end{tabular}

\begin{tabular}{|c|c|c|c|}
\hline \multirow{2}{*}{. } & \multicolumn{3}{|c|}{ ANalysis of Variance } \\
\hline & $d / f$ & $\begin{array}{l}\text { Sums of } \\
\text { Squares }\end{array}$ & $\begin{array}{l}\text { Mean } \\
\text { Squa e }\end{array}$ \\
\hline 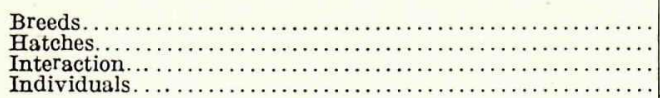 & $\begin{array}{r}2 \\
2 \\
4 \\
257\end{array}$ & $\begin{array}{r}.3381 \\
.0850 \\
.0123 \\
1.1095\end{array}$ & $\begin{array}{l}.1690^{* *} \\
.0425^{* *} \\
.0031 \\
.0043\end{array}$ \\
\hline
\end{tabular}

1 Figures in parenthesis are number of birds.

\section{Chick mortality}

Table 12 shows the chick mortality of the three breeds for 1946 and 1947.

TABLE No. 12

MORTALITY TO ONE MONTH OF AGE OF WHITE LEGHORNS, NEW HAMPSHIRES, AND NATIVES

\begin{tabular}{|c|c|c|c|c|c|}
\hline \multirow[b]{2}{*}{ YEAR } & \multirow[b]{3}{*}{$\begin{array}{l}\text { Number hatched } \ldots \ldots \ldots \ldots \ldots \ldots \ldots \ldots \ldots \ldots \\
\text { No. alive at } 1 \text { month } \ldots \ldots \ldots \ldots \ldots \ldots \ldots \ldots \ldots \\
\text { Per cent alive } \ldots \ldots \ldots \ldots \ldots \ldots \ldots \ldots \ldots\end{array}$} & \multicolumn{4}{|c|}{ B R E E D } \\
\hline & & $\begin{array}{l}\text { White } \\
\text { Leghorn }\end{array}$ & $\begin{array}{l}\dot{\text { New }} \\
\text { Hamp- } \\
\text { shire }\end{array}$ & Native & $\begin{array}{l}\text { Un- } \\
\text { weighted } \\
\text { mean }\end{array}$ \\
\hline $1946 \ldots \ldots$ & & $\begin{array}{l}135 \\
115 \\
(85.19)\end{array}$ & $\begin{array}{l}145 \\
122 \\
(84.14)\end{array}$ & $\begin{array}{l}121 \\
108 \\
(89.26)\end{array}$ & $(86.20)$ \\
\hline $1947 \ldots \ldots$ & 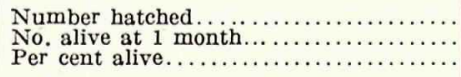 & $\begin{array}{l}220 \\
198 \\
(90.00)\end{array}$ & $\begin{array}{l}616 \\
567 \\
(92.05)\end{array}$ & $\begin{array}{l}288 \\
271 \\
(94.10)\end{array}$ & $(95.05)$ \\
\hline $\begin{array}{l}\text { Com- } \\
\text { bined } \\
\text { years }\end{array}$ & 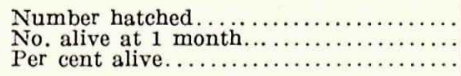 & $\begin{array}{l}355 \\
313 \\
(88.17)\end{array}$ & $\begin{array}{l}761 \\
689 \\
(90.54)\end{array}$ & $\begin{array}{l}409 \\
379 \\
(92.67)\end{array}$ & $(90.46)$ \\
\hline
\end{tabular}

The New Hampshire chicks had 7.91 per cent better viability during 1947 than during 1946. A chi-square of 7.68 was obtained, which was highly significant, the probability being 
less than .01 for one degree of freedom. However, there were no significant differences between years in respect to the White Leghorn and Native breeds. Also breed differences were not significant in either year.

\section{Laying flock mortality}

Table 13 gives the laying flock mortality of the three breeds for 1946 and 1947.

TABLE No. 13

LAYING FLOCK MORTALITY OF WHITE LEGHORNS, NEW HAMPSHIRES, AND NATIVES

\begin{tabular}{|c|c|c|c|c|c|}
\hline Year & 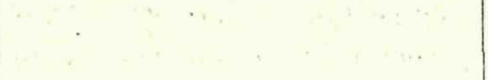 & $\begin{array}{l}\text { White } \\
\text { Leghorn }\end{array}$ & $\begin{array}{l}\text { New } \\
\text { Hamp- } \\
\text { shire }\end{array}$ & Native & $\begin{array}{l}\text { Un- } \\
\text { weighted } \\
\text { mean }\end{array}$ \\
\hline $1946 \ldots$ & 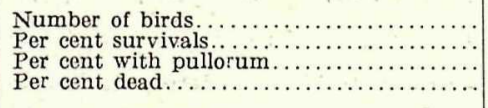 & $\begin{array}{l}91 \\
21.98 \\
48.35 \\
29.67\end{array}$ & $\begin{array}{l}137 \\
34.31 \\
48.17 \\
17.52\end{array}$ & $\begin{array}{l}58 \\
36.21 \\
37.93 \\
25.86\end{array}$ & $\begin{array}{l}30.83 \\
44.82 \\
24.35\end{array}$ \\
\hline $1947 \ldots$ & 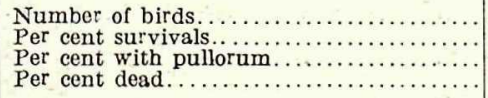 & $\begin{array}{r}64 \\
60.94 \\
4.69 \\
34.37\end{array}$ & $\begin{array}{r}219 \\
78.08 \\
0.91 \\
21.01\end{array}$ & $\begin{array}{r}44 \\
52.27 \\
6.82 \\
40.91\end{array}$ & $\begin{array}{r}63.76 \\
4.14 \\
32.10\end{array}$ \\
\hline
\end{tabular}

The New Hampshire birds had 17.14 per cent better viability than the White Leghorns and 25.81 per cent better viability than the Natives during 1947. A chi-square of 16.04 was obtained, which was highly significant, the probability being less than .01 for two degrees of freedom. There were no significant differences between the White Leghorns and the Natives during the same year.

If birds culled because of pullorum in 1946 are not included among the dead, the laying flock mortality was 23.64 per cent lower in the New Hampshires than in the White Leghorns. With a chi-square of 6.45 this difference was significant, the probability being less than .02 for one degree of freedom. However, there were no significant differences between the New Hampshires or the Leghorns and the Natives. If birds culled because of pullorum in 1946 are included among the dead there were no significant differences between the breeds in mortality during that year.

The New Hampshires had 43.77 per cent better viability in 1947 than in 1946. A chi-square of 66.2 was obtained, with a probability of less than .01 for one degree of freedom.

There were no significant differences in laying flock mortality of the Natives between the years. 


\section{Comparison of Crosses}

Table 14 summarizes the average egg production, sexual maturity, egg weight, and body weight of the crossbreds and the parental breeds. The data on the chick and laying flock mortality is shown in table 15 .

\section{White Leghorn $x$ Native vs. White Leghorn and Native}

The White Leghorns laid an average of 12.0 eggs more than the White Leghorns $x$ Natives during the period studied (Table 14). A t value of 3.48 was obtained with 135 degrees of freedom, the probability being less than .01. The White Leghorn $\mathrm{x}$ Natives laid an average of 12.5 eggs more than the Natives. With a $t$ value of 3.38 and 100 degrees of freedom the probability was less than .01. The Native birds were more uniform than the other breeds in egg production. The variation within the crossbreds was intermediate between that found in the Leghorns and the Natives. The standard deviation in production was $21.89,18.43$, and $15.42 \mathrm{eggs}$ respectiveiy for the Leghorns, White Leghorn $\mathrm{x}$ Natives, and Natives.

There were no significant differences in the sexual maturity of the three breeds (Table 14). However, the variation within the Natives and the crossbreds was much higher than that found within the Leghorns. The standard deviation in sexual maturity was $22.9,44.84$, and 52.07 days for the Leghorns, Crossbreds, and Natives, respectively.

TABLE NO. 14

EGG PRODUCTION, SEXUAL MATURITY, EGg WEIGHT, AND BODY WEIGHT OF THE WHITE LEGHORNS, NEW HAMPSHIRES, NATIVES AND CROSSES BETWEEN THEM

\begin{tabular}{|c|c|c|c|c|c|c|c|c|}
\hline \multirow[b]{2}{*}{ Breed } & \multirow[b]{2}{*}{$\mathrm{N}$} & \multirow{2}{*}{$\begin{array}{c}\text { Egg } \\
\text { produc- } \\
\text { tion } \\
(\text { Mean- } \\
120 \text { days })\end{array}$} & \multirow{2}{*}{$\begin{array}{l}\text { Age } \\
\text { at } \\
\text { first } \\
\text { egg } \\
\text { (days) }\end{array}$} & \multirow{2}{*}{$\begin{array}{l}\text { Mean } \\
\text { egg } \\
\text { weight } \\
\text { (oz. } \\
\text { per } \\
\text { dozen) }\end{array}$} & \multicolumn{4}{|c|}{ Body weight (pounds) } \\
\hline & & & & & $\begin{array}{c}\text { One } \\
\text { month }\end{array}$ & $\begin{array}{c}\text { Two } \\
\text { months }\end{array}$ & $\begin{array}{l}\text { Three } \\
\text { months }\end{array}$ & $\begin{array}{l}\text { Four } \\
\text { month }\end{array}$ \\
\hline 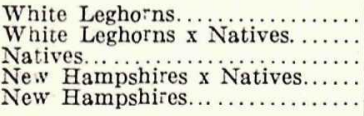 & $\begin{array}{r}68 \\
69 \\
33 \\
55 \\
165\end{array}$ & $\begin{array}{l}45.7 \\
33.7 \\
21.2 \\
39.9 \\
47.8\end{array}$ & $\begin{array}{l}192 \\
202 \\
195 \\
222 \\
225\end{array}$ & $\begin{array}{l}\text { 19. } 3 \\
18.3 \\
16.9 \\
19.0 \\
20.9\end{array}$ & $\begin{array}{l}0.56 \\
0.48 \\
0.45 \\
0.49 \\
0.57\end{array}$ & $\begin{array}{l}\text { 1. } 40 \\
\text { 1. } 20 \\
\text { 1. } 11 \\
\text { 1. } 25 \\
1.45\end{array}$ & $\begin{array}{l}\text { 2. } 31 \\
\text { 1. } 98 \\
\text { 1. } 64 \\
\text { 2. } 13 \\
\text { 2. } 49\end{array}$ & $\begin{array}{l}\text { 3. } 02 \\
2.44 \\
\text { 2. } 16 \\
\text { 2. } 64 \\
\text { 3. } 21\end{array}$ \\
\hline
\end{tabular}


TABLE NO. 15

CHICK AND LAYING FLOCK MORTALITY OF WHITE LEGHORNS, NEW HAMPSHIRES, NATIVES AND CROSSES BETWEEN THEM

\begin{tabular}{|c|c|c|c|c|c|c|c|}
\hline \multirow[b]{2}{*}{ Brced } & \multicolumn{3}{|c|}{ Chick Mortality } & \multicolumn{4}{|c|}{ Laying Flock Mortality } \\
\hline & $\begin{array}{l}\text { Number } \\
\text { hatched }\end{array}$ & $\begin{array}{l}\text { Number } \\
\text { alive at } \\
\text { one } \\
\text { monih }\end{array}$ & $\begin{array}{l}\text { Per Cent } \\
\text { alive at } \\
\text { one } \\
\text { moith }\end{array}$ & $\mathrm{N}$ & Survivals & $\begin{array}{l}\text { With } \\
\text { pullorum }\end{array}$ & Dead \\
\hline . & & & ' & & Per cent & Per cent & Per cent \\
\hline 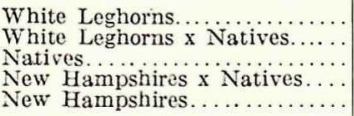 & $\begin{array}{l}220 \\
493 \\
288 \\
665 \\
616\end{array}$ & $\begin{array}{l}198 \\
471 \\
271 \\
625 \\
567\end{array}$ & $\begin{array}{l}90.00 \\
95.54 \\
94.10 \\
93.98 \\
92.05\end{array}$ & $\begin{array}{r}64 \\
122 \\
44 \\
111 \\
219\end{array}$ & $\begin{array}{l}60.94 \\
69.67 \\
52.27 \\
70.27 \\
78.08\end{array}$ & $\begin{array}{l}4.69 \\
4.10 \\
6.82 \\
1.80 \\
0.91\end{array}$ & $\begin{array}{l}34.37 \\
26.23 \\
40.91 \\
27.93 \\
21.01\end{array}$ \\
\hline
\end{tabular}

The Leghorns laid heavier eggs than the White Leghorn $\mathrm{x}$ Natives, with an average of $1 \mathrm{oz}$. per dozen eggs more (Table 14). A $t$ value of 5.25 was obtained with 135 degrees of freedom, corresponding to a probability of less than .01 that this is a chance difference. The crossbreds laid an average of $1.4 \mathrm{oz}$. per dozen heavier eggs than the Natives. With a $t$ of 5.16 and 100 degrees of freedom the probability was less than .01. The Natives laid eggs which varied more in size than those laid by the Leghorns and the crossbreds. The standard deviation in egg weight was $1.23,1.16$, and 1.48 oz. per dozen eggs for the Leghorns, White Leghorns x Natives and Natives, respectively.

The weight of the White Leghorn birds were $0.08,0.20,0.33$, and 0.58 pounds more than that of the crossbreds at the end of the first, second, third, and fourth month of age, respectiveiy (Table 14). For 135 degrees of freedom the probability was less than .01 in all cases that these are chance differences. The $t$ values obtained were $5.79,6.67,6.56$, and 11.12 , respectively, for each of the four months. The weights of the crossbreds were similar to the Natives for the first month of age but they were $.09, .34$, and .28 pounds heavier at the second, third, and fourth months, respectively. For 100 degrees of freedom the probability was less than .01 . The $t$ values for testing significance were $2.72,5.38$, and 4.93 for the second, third, and fourth months, respectively. The variation in weight within the crossbreds was more or less intermediate between that found in the Leghorns and the Natives in all months except the third. The standard deviations of their weights during each of the four months were $.08, .16, .31$, and .27 pounds as compared with .09 , $.19, .28$, and .33 pounds for the Leghorns and $.07, .15, .26$, and .27 pounds for the Natives. 
The White Leghorns x Natives had 5.54 per cent better chick viability than the White Leghorns (Table 15). A chi-square of 8.27 was obtained, which has a probability of less than .01 for one degree of freedom. There were no significant differences between the crossbreds and the Natives in chick mortality.

The White Leghorn x Native laying hens had 17.40 per cent better viability than the Natives (Table 15). With one degree of freedom, a chi-square of 4.49 was significant for a probability less than .05 . There were no significant differences between the crossbreds and the Leghorns in laying flock mortality.

\section{New Hampshire $x$ Native vs. New Hampshire and Native}

The New Hampshires laid an average of 7.9 eggs more than the New Hampshire $\mathrm{x}$ Natives during the period studied (Table 14). A t value of 2.66 was obtained which was highly significant $(P \times .01)$ for 218 degrees of freedom. The crossbreds laid an average of 18.7 eggs more than the Natives. A t value of 5.45 obtained with 86 degrees of freedom had a probability of less than .01. The variation within the crossbreds and the Natives was less than that found in the New Hampshires. The standard deviation in production was 19.99, 15.69, and 15.42 eggs for the New Hampshires, New Hampshires $x$ Natives, and Natives, respectively.

The Natives were 27 days earlier in maturity than the crossbreds (Table 14). The $t$ value calculated was 2.43 , which for 86 degrees of freedom has a probability of less than .05 . There were no significant differences between the crossbreds and the New Hampshires. The Natives and the New Hampshire $x$ Natives varied more in maturity than the New Hampshires. The standard deviation in sexual maturity were 41.32, 49.59, and 52.07 days for the New Hampshires, crossbreds and Natives, respectively.

The New Hampshires laid eggs weighing 1.9 oz. per dozen more than those laid by the crossbreds (Table 14). A t value of 7.29 was obtained, the probability being less than 0.1 for 218 degrees of freedom. The New Hampshires $x$ Natives laid eggs averaging $2.1 \mathrm{oz}$. per dozen heavier than the Natives. With a $t$ value of 6.35 and 86 degrees of freedom the probability was less than .01. The variation in egg weight was more marked within the New Hampshires and the crossbreds than within the Natives. The standard deviations in egg weight 
were $1.60,1.59$, and 1.48 oz. per dozen eggs for the New Hamp- . shires, New Hampshire $x$ Natives and the Natives, respectively.

The weight of the New Hampshire birds was $.08, .20, .36$, and .57 pounds more than that of the crossbreds at the end of the first, second, third and fourth month of age, respectively (Table 14). For 218 degrees of freedom the probability was less than .01 in ail cases; the $t$ values obtained being 7.41 , $6.34,6.11$, and 8.14 for each of the four months. The crossbreds were $.04, .14, .49$, and .48 pounds heavier than the Natives at the end of the first, second, third and fourth month of age, respectively. For 86 degrees of freedom the probability was less than .05 at the first month and less than .01 at the second, third and fourth month. The corresponding $t$ values were $2.32,3.56,7.99$, and 5.24 for each month. The standard deviations in body weight of the crossbreds during each of the four months were $.09, .19, .29$, and .49 pounds as compared with $.06, .20, .39$, and .43 pounds for the New Hampshires and with $.07, .15, .26$, and .27 pounds for the Natives.

There were no significant differences between the breeds in chick mortality (Table 15).

The New Hampshire $\mathrm{x}$ Natives had 18 per cent better laying flock viability than the Natives (Table 15). A chi-square of 4.31 was obtained, which was significant at the .05 level of probability. There were no significant differences between the crossbreds and the New Hampshires in laying flock mortality.

\section{New Hampshire $x$ Native vs. White Leghorn $x$ Native}

There were no significant differences in egg production between the crossbreds although the New Hampshires $\mathrm{x}$ Natives had a tendency to lay better (Table 14).

The White Leghorn $\mathrm{x}$ Natives were 20 days earlier in maturity than the New Hampshires $x$ Natives (Table 14). The $t$ value obtained was 2.31 and the probability was less than .05 for 122 degrees of freedom.

The New Hampshires x Natives laid eggs weighing $0.7 \mathrm{oz}$. per dozen more than those laid by the White Leghorn $\mathrm{x}$ Natives (Table 14). With a $t$ value of 3.15 the probability was less than .01 for 122 degrees of freedom.

The weight of the New Hampshire $\mathrm{x}$ Native birds was .01, $.05, .15$, and .20 pounds more than that of the White Leghorn $\mathrm{x}$ Natives (Table 14). The differences were not significant during the first two months. At the third and fourth months of 
age the New Hampshire $\mathrm{x}$ Natives were significantly heavier than the White Leghorns $x$ Natives. A t value of 2.86 for the third month and of 2.92 for the fourth month was obtained; the probability was less than .01 for 122 degrees of freedom.

The growth curves of the crossbreds and purebreds are presented in Figure 1.

The crossbreds were more or less alike in chick mortality and laying flock mortality. However, both crossbreds, with a percentage chick viability of 94.65 , were significantly superior to the purebreds (White Leghorn, New Hampshire, Native) with a percentage chick viability of 92.17. A chi-square of 5.69 was obtained with a probability of less than .02 for one degree of freedom. 


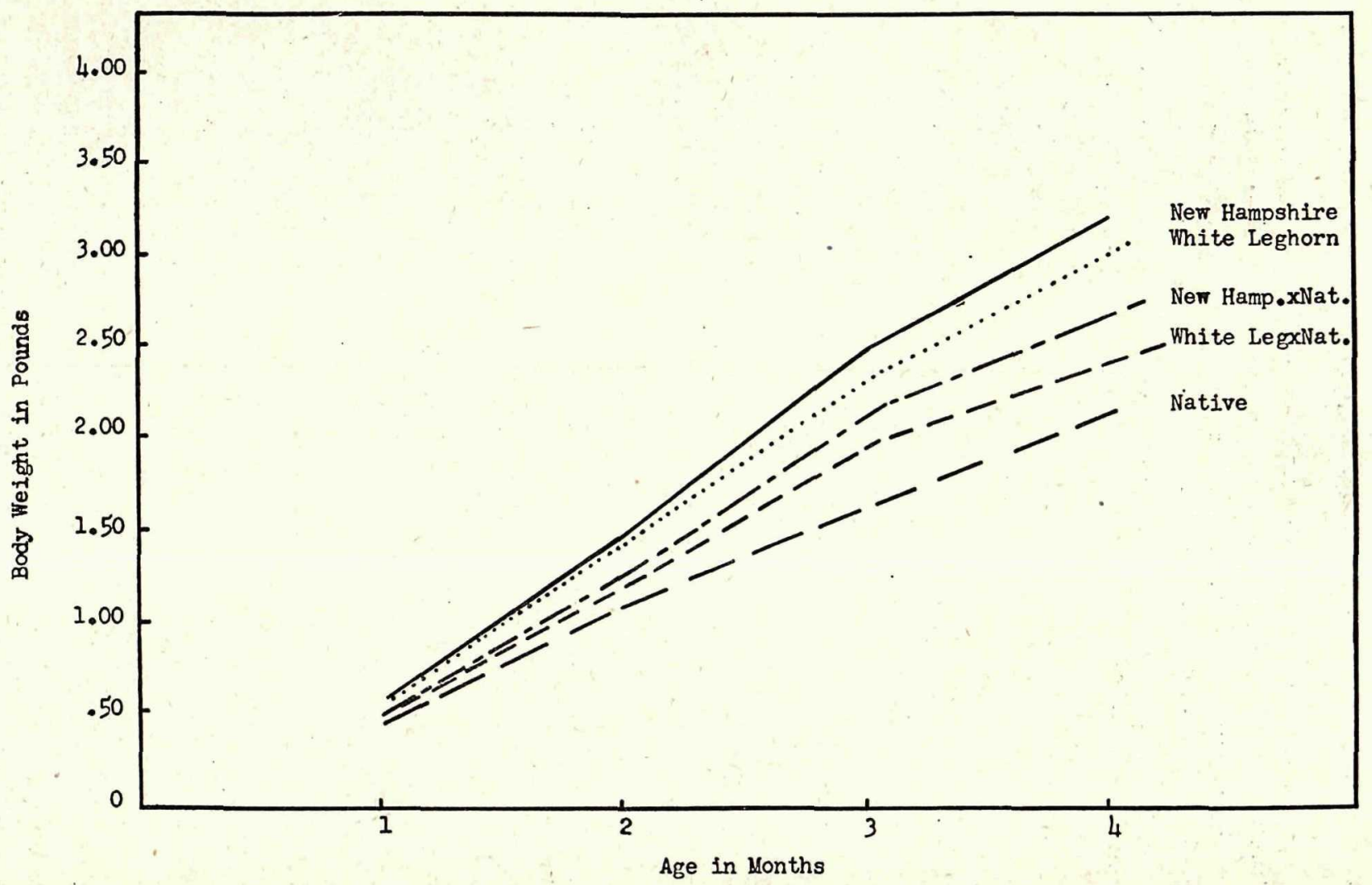

号

FIG. 1.-Comparative growth to four months of purebred and crossbred chickens. 


\section{Discussion}

Practical and important differences were found between the Native Puerto Rican fowl and the standard breeds in respect to their productive capacity. As regards egg production, egg weight, and body weight the native fowl would appear to contribute very little, if anything, to the attainment of a more productive breed for Puerto Rico. The differences between the Native and the standard breeds in those characters, viz. 21.2 eggs in production during the first 120 days of laying, $3.5 \mathrm{oz}$. per dozen in egg weight, and $1.05 \mathrm{lbs}$. in body weight at the end of the fourth month of age, are quite conclusive and indicative of the advisability of substituting for the Native breed a more productive breed as a first step for increasing poultry production in the Island.

The superiority of the standard breeds in respect to sexual maturity was not so evident but the study of this character is only useful as a help in evaluating egg production. Laying flock mortality was heavy for all the breeds but the New Hampshires fared better than the Natives. However, the conditions of this experiment were such as to enable the native fowls to fully express their potentiality in respect to body weight, egg production and egg weight but it is questionable if they were adequate to enable them to fully express their potentiality in the qualities of viability and resistance to disease. The natural habitat of the native fowl in the Island is very different from that used in this experiment where, although S. pullorum was present in the flock, the birds were protected as far as possible against adverse conditions and against disease and parasites.

Some improvement through adequate selection within the Native breed is considered possible, but on the basis of the results shown the use of other possibilities available for the development of a better breed for Puerto Rico seems more practical and economical.

Assuming that selection would be exclusively for egg production and that the effectiveness of the selection practiced were 100 per cent; that the females and males kept for replacement purposes were 20 and 2 per cent, respectively, of the population available; that the standard deviation in production would remain more or less constant around 15 eggs, which was the figure obtained in 1947; and that the heritability of egg pro- 
duction is of the order of 10 per cent; the time required to raise the egg production of the Natives from an average of 21.2 eggs during the first 120 days of laying to the average of the New Hampshire, 47.8 eggs would be around 9 generations or approximately 14 years (Lush, 1945). Actually, much more than 14 years would be necessary to raise the egg production of the Natives to a level comparable with that of the New Hampshires because the selection could not be done for egg production alone and its effectiveness would be much less than 100 per cent. Also the replacement percentage probably would be higher due to the high mortality rates in the flocks of the Island.

The crosses represent a distinct improvement over the Natives in respect to the productive characters but they are inferior to the standard breeds in egg production, egg weight, and body weight: Their production and egg weight was intermediate between that of the Natives and the standard breeds. Body weight was slightly nearer the smaller sized breed. Similar results were obtained with other breeds by Jull and Quinn and by Maw, cited by Jull (1946). In respect to sexual maturity, the White Leghorn cross was similar to the White Leghorn while the New Hampshire cross was similar to the New Hampshire.

There is some indication in the data that the crosses may perform better than the standard breeds in respect to resistance and viability although that is not so apparent when comparing them with the New Hampshire. The ultimate value of the crosses as a possibility for developing a better breed for Puerto Rico will depend upon the existence of actual resistance or adaptability in the Native stock, that is, in the contribution, if any, that the Native can give to a new breed. ${ }^{1}$

The possibility of developing some strain from one of the standard breeds which will make it more desirable than the Native for Puerto Rican conditions is apparent from this study. The New Hampshire breed was superior to the White Leghorn in egg weight, body weight, and mortality. They were similar in egg production and the New Hampshire was inferior only in sexual maturity. Except in chick mortality and sexual maturity the New Hampshire stock surpassed the Native breed in all characters. So far as the characters studied are concerned

1 The breeding work is being continued at the Station with several backeross lines. 
the New Hampshire seems to offer a distinct possibility for developing a strain which would be more desirable than the Native for Puerto Rico.

However, in some of the characters, especially in egg production and egg weight, the standard breeds in this study were inferior to selected flocks in the United States. This lower production and smaller egg size may have been due to a physiological response of the birds in their adaptation to a tropical environment. Results obtained by Warren $(1933,1939)$ tend to indicate that the smaller egg size could be due to environmental effects. This possibility, however, should be further investigated.

Seasonal effects were found to be important in this study in respect to egg production, sexual maturity, egg weight, and body weight at the end of the first month of age. Differential responses of the birds of the different breeds to these seasonal effects were apparent in respect to sexual maturity and body weight at the end of the first month of age. This environmental influence was more evident from February to June than from February to March.

\section{CONCLUSIONS}

Much more information would be necessary before a definite conclusion on the main objectives of this study could be advanced. However, it is considered that sufficient evidence has been collected to justify drawing the following conclusions:

1. The productive capacity of the Native fowl, as judged by egg production, egg weight, and body weight, is inferior to that of the standard breeds studied.

2. Selection within the Native would be a long and noneconomical proposition as a means of getting a better breed of poultry for the Island.

3. Crosses between the Native and the standard breeds will show some improvement over the pure Natives but will be inferior to the standard breeds in their productive capacity.

4. There is no definite or immediately pparent superiority of the Natives in respect to viability and resistance over the imported breeds under the conditions in which this experiment was made.

Due to the peculiarities of the poultry management and care in the small farms of the Island it would be desirable to study 
the same characters considered here under those conditions. The study should be extended to include fertility, hatchability, mortality during the growing period, efficiency of food utilization, resistance to parasites (which constitutes an important problem in the Island), and physiological responses of the different breeds to the environment. Studies of this nature should be undertaken under experimental and farm conditions.

Allowance for the date of hatching, as a factor influencing some of the characteristics studied here, should be made when planning further comparisons between breeds. The advisability of including other strains of White Leghorns and New Hampshires for comparison and crossing purposes should also be considered in future plans.

It is felt that the ideal fowl for Puerto Rico would possibly be a medium size bird, with high efficiency of food utilization, laying relatively well, with some broodiness and good adaptability to the environment. Such a bird, replacing the Native stock, would increase poultry meat and egg production in the Island with minimum expense on the part of the farmer.

\section{SUMMARY}

The productive capacity of the Native Puerto Rican fowl was compared with White Leghorns and New Hampshires reared under similar conditions. Data were recorded on egg production, sexual maturity, egg weight, body weight to four months of age, and mortality. Studies of an exploratory nature were made of the possibilities of crosses between the $\mathrm{Na}$ tive and the standard breeds.

It was found that the productive capacity of the Native fowl, as judged by egg production, egg weight and body weight, was inferior to that of the White Leghorn and New Hampshire. The Native crosses showed improvement over the pure Natives, but were inferior to the standard breeds although there was some indication that they may possess a greater amount of disease resistance.

Under the conditions of the experiment there was no apparent superiority of the pure Natives over the imported breeds in respect to viability and resistance.

Extension of the study to cover the physiological responses of the different breeds to the environment under experimental and farm conditions is recommended. 
298 JOURNAL OF AGRICULTURE OF UNIVERSITY OF PUERTO RICO

\section{ACKNOWLEDGEMENT}

The author wishes to express sincere appreciation to Dr. A. W. Nordskog, of the Iowa State College, for his helpful guidance and counsel in the preparation of this manuscript; to $\mathrm{Mr}$. J. I. Cabrera, of the Agricultural Experiment Station of the University of Puerto Rico for his valuable assistance in the tabulation and analysis of the data; and to Miss Elba Guzmán, of the Agricultural Experiment Station of the University of Puerto Rico, for her suggestions and help in the preparation of the manuscript. 


\section{IITERATURE CITED}

Asmundson, V. S. and W. E. LLOYD, 1936. Effect of season on the growth and feed consumption of turkeys. Poul. Sci., 15:186.

Barott, H. G. and E. M. Pringle, 1941. Energy and gaseous metabolism of the hen as affected by temperature. Jour. of Nutrition, 22:273.

Bennion, N. L. and D. C. WARren, 1933. Temperature and its effect on egg size in the domestic fowl. Poul. Sci., 12:69-82.

Bissonnette, T. H., 1933. Does increased light absorption cause increased egg production? Poul. Sci., 12:396-399.

BRAY, C. I., 1932. Value of a Brahman cross on native and grade beef cattle in southern Louisiana. Amer. Soc. Anim. Prod. Proc., 25:72-76.

BRoDy, S., 1940. Reactions of animals to temperature, humidity and air movement. Agr. Eng., 21:265.

BurRows, W. H. and T. C. BYERLY, 1938. The effect of certain groups of environmental factors upon the expression of broodiness. Poul. Sci., $17: 324$.

Byerly, T. C., C. W. KNox, and M. A. JuLL, 1934. Some genetic aspects of hatchability. Poul. Sci., 13:230-238.

DudLEy, F. J., 1928. The death rate of three standard breeds of fowls during the pullet year. Poul. Sci., 7:245.

Dunn, L. C., 1922. Hatchability and chick mortality. Poul. Sci., 1:33.

Forbes, E. B. and others, 1926. The influence of the environmental temperature on the heat production of cattle. Jour. Agr. Res. 33:579-589.

French, M. H., 1940. Some observations on poultry. The E. African Agr. Jour., $6: 109$.

Funk, E. M., H. C. KNANDel and E. W. Callenbach, 1930. Statistical studies of the variations in the growth of Single Comb White Leghorns and their significance. Poul. Sci., 9:157.

GaAlAAS, R. F., 1947. A study of heat tolerance in Jersey cows. Jour. Dairy Sci., 30:79.

Goulden, C. H., 1939. Methods of statistical analysis. John Wiley and Sons. N. Y. 40-41.

GOVERNOR OF PUerto Rico, 1948. Forty-seventh annual report, fiscal year 1946-47:30.

HARRIS, J. A., 1922. The correlation between monthly and annual egg production in the pullet year in the White Wyandotte fowl. Poul. Sci., $1: 196$.

Harris, J. A., and D. C. Boughton, 1928. The death rates of three standard breeds of fowls. Poul. Sci., 7:120. 
Harris, M. F., 1947. La temperatura de Puerto Rico. Dept. de Agric. y Comercio de Puerto Rico. Almanaque Agrícola :75-82.

HAYS, F. A. and R. SANBORN, 1939. Factors affecting fertility in Rhode Island Reds. Mass. Agr. Exp. Sta. Bul. 359.

Heinbecker, P., 1928. Studies on the metabolism of eskimos. Jour. Biol. Chem., $80: 461$.

Hutr, F. B., 1935. On the physiology of the genetic resistance to Salmonella Pullorum in the fowl. Amer. Nat., 69:66-67.

HutT, F. B., 1938. Genetic of the fowl. VIII. Breed differences in susceptibility to extreme heat. Poul. Sci., 17:454.

Hyre, H. M. and G. O. HALL, 1932. The constancy of hatching power in hens. Poul. Sci., 11:166-171.

JULL, M. A., 1946. Poultry breeding. 2d ed. John Wiley and Sons, N. Y. 227, 261, 263, 266.

Jull, M. A. and A. B. Godfrey, 1933. Mean annual egg weight in relation to mean weight of first ten eggs laid. Poul. Sci., 12:310.

Kempster, N. L., 1938. The influence of summer temperature on the rate of growth of chickens. Poul. Sci., 17:259.

LAMbert, W. V., 1935. Inheritance as a factor in poultry disease. Poul. Sci., $14: 131-136$.

LAMOREUX, W. F., 1943. Environmental temperature and infertility in White Leghorn. Poul. Sci., 21:18.

LAMoreux, W. F. and F. B. Hutt, 1939. Breed differences in resistance to a deficiency of vitamin B in the fowl. Jour. Agr. Res., 58:307.

LeE, D. H. K. and K. Robinson, 1941. Reactions of the sheep to hot atmospheres. Proc. Roy. Soc. Queensland, 53:189.

LeE, D. H. K., K. Robinson and H. J. G. Hines, 1941. Reactions of the rabbit to hot atmospheres. Proc. Roy. Soc. Queensland, 53:129.

Lorenz, F. W. and H. J. Almquist, 1936. Seasonal variations in egg quality. Poul. Sci., 15:14-18.

Lush, J. L., 1945. Animal breeding plans. 3rd. ed. Iowa State College Press, Ames, Iowa.

MANN, G. E., 1941. Seasonal loss of condition in Rhode Island Red and other fowls in Malaya. Malayan Agr. Jour., 29:107-117.

ManresA, M. and S. C. OrIG, 1941. Hematological studies on cattle. IV. Variations in hemoglobin and white blood cells in the Philippine native breed of cattle. Philippine Agr., 30:375.

Marshal, F. N. A., 1937. On the change over in the oestrous cycle in animals after transference across the Equator, with further observations on the incidence of the breeding seasons and the factors controlling sexual periodicity. Proc. Roy. Soc. London, Sec. B. 122:413-428.

MASON, E. D., 1940. Effect of change of residence from temperate to tropical climate on basal metabolism, weight, pulse rate, blood pressure, 
and mouth temperature of 21 English and American women. Amer. Jour. Trop. Med., 20:669.

McConnell, W. J. and C. P. YAGLOGLou, 1935. Basal metabolism as affected by atmospheric conditions. Arch. Intern. Med., 36:382.

Morgan, C. L., 1932. Relationship between breaking strength and the per cent of egg shell. Poul. Sci., 11:172.

MUKherJeE, H. N. and P. C. GuptA, 1931. The basal metabolism of Indians. Indian Jour. of Med. Res. 18:807.

Patterson, R. E., 1946. The use of adjusting factors in the analysis of data with disproportionate subclass numbers. Jour. Amer. Statistical Ass., 41:334-346.

PEARL, R., 1923. Duration of life as an index of constitutional fitness. Poul. Sci., $3: 1$.

Puerto Rico Bureau of Commerce, 1947. Annual book on statistics of Puerto Rico. Puerto Rico Dept. of Agr. and Commerce, fiscal year 194546. $89-90$.

REGAN, W. M. and G. A. RICHARDSON, 1938. Reactions of the dairy cow to changes in environmental temperature. Jour. Dairy Sci., 21:73-79.

Resananda, NAI ThoNGdee, 1924. Determination of the best season for hatching eggs in the Philippines. Philippine Agr., 13:81.

RhoAd, A. O., 1935. The dairy cow in the tropics. Amer. Soc. Anim. Prod. Proc., 28:212-214.

RHOAD, A. O., 1936. The influence of environmental temperature on the respiratory rhythm of dairy cattle in the tropics. Jour. Agr. Sci., 26:36.

RHOAD, A. O., 1938. Some observations on the response of purebred Bos taurus and Bos indicus cattle and their crossbred types to certain conditions of the environment. Amer. Soc. Anim. Prod. Proc., 31:284-295.

RHOAD, A. O., 1940. A method of assaying genetic differences in the adaptability of cattle to tropical and subtropical climates. Emp. Jour. of Exp. Agr., 8:190.

RHOAD, A. O., 1941. Climate and livestock production. U. S. Dept. Agr. Year book. Climate and Man., 508-514.

RHOAD, A. O., 1942. A scale of heat tolerance for cattle. Jour. Anim. Sci., $1: 85$.

ROBERTS, E. and L. E. CARD, 1926. The inheritance of resistance to bacillary white diarrhea. Poul. Sci., 6:18.

Robinson, K. and D. H. K. LeE, 1941 a. Reactions of the cat to hot atmospheres. Proc. Roy. Soc. Queensland, 53:159.

RoBInson, K. and D. H. K. LEE, 1941 b. Reactions of the dog to hot atmospheres. Proc. Roy. Soc. Queensland, 53:171.

Robinson, K. and D. H. K. Lee, 1941 c. Reactions of the pig to hot atmospheres. Proc. Roy. Soc. Queensland, 53:145.

RoDdis, L. H. and G. W. Cooper, 1926. The effect of climate on blood pressure. Jour. Amer. Med. Ass., 87:2053-2055. 
Seath, D. M., 1947. Heritability of heat tolerance in dairy cattle. Jour. Dairy Sci., 30:137.

Sherman, H. C., 1941. Chemistry of food and nutrition. 6th. ed. Macmillan Co., N. Y. 168.

SNEDECoR, G. W., 1946. Statistical methods. 4th. ed. Iowa State College Press, Ames, Iowa 296-299.

TAYLOR, L. W. and J. H. MARTIN, 1928. Factors influencing thickness of egg shell. Poul. Sci., 8:39.

Thompson, W. C., 1933. Significance of short-time egg yield records. Poul. Sci., 12:179.

Thorp, J., 1941. Climate and settlement in Puerto Rico and the Hawaiian Islands. U. S. Dept. of Agr. Yearbook. Climate and Man., 217-226.

U. S. BUREAU OF Home Economics, 1933. Diets at four levels of nutritive content and cost. U. S. Dept. of Agr. Circular 296.

U. S. 16Th. CENsus, 1940. Puerto Rico, population :1.

WARREN, D. C., 1926. Genetics of breed characteristics. Poul. Sci., 5:209.

WARREN, D. C., 1927. Hybrid vigor in poultry. Poul. Sci., $7: 1$.

WARREN, D. C., 1930. The effect of disturbance upon the rhythm of egg production. Poul. Sci., 9:184.

WARREN, D. C., 1939. Effect of temperature on size of eggs from pullets in different latitudes. Jour. Agr. Res. 59:441-452.

Whetham, E. O., 1933. Factor modifying egg production with special reference to seasonal changes. Jour. of Agr. Sci., 23:383-411.

YeAtes, N. T. M., D. H. K. LEE and H. J. G. Hines, 1941. Reactions of domestic fowls to hot atmospheres. Proc. Roy. Soc. Queensland, 53:105. 